\title{
WALRUS: THE SENSITIVE GIANT IN THE ERA OF CLIMATE CHANGE: CLIMATIC ADAPTATION AND CHALLENGES
}

\author{
UDC 551.583
}

\author{
Apostolos Tsiouvalas \\ Intern at PAME Secretariat, Akureyri, Iceland
}

\begin{abstract}
There is no doubt that the cryosphere is changing, the planet's temperature is increasing and ice is retreating. Earth is gradually experiencing the repercussions of global warming which are most visible at high latitudes, and especially in the Arctic, the home of Odobenus Rosmarus or simply Walrus. The walrus is one of the most icedependent species. Walruses use sea ice for crucial behaviours like giving birth, feeding and resting. As the seasonal dynamics of ice cover on arctic seas change, walruses tend to congregate on coasts without ice. Thanks to this adaptation of walruses to different climate trends they have successfully survived and conserved their populations. Its adaptability has been the driving force behind preventing the walrus from being listed as an endangered species. Some scientists are attributing this trend to a normal adaptive behaviour of the mammal, while others already have noticed a risk violently posed by climate change. This article is motivated by the announcement of the U.S. Fish and Wildlife Service that the walruses were unlikely to be considered endangered in the foreseeable future, addresses the vulnerability of walruses to climate change, explaining their dependence on sea ice and the need for reconsideration of the above statement.
\end{abstract}

Key words: walrus, climate change, adaptation

\section{INTRODUCTION}

The walrus can be easily recognized by its enormous size and its impressive tusks. Walruses are large marine mammals which can weigh more than 2,000 kg (4,400 lb) and belong to the category of Pinnipeds [1]. It is distributed with two distinct subspecies within disparate ranges, the Atlantic walrus, O. r. rosmarus, and the Pacific walrus, O. r. divergens [2]. The total walrus population is nowadays estimated to be close to 225,000 distributed in continental shelves around the Atlantic Ocean, the Pacific Ocean and the Laptev Sea [3]. The biggest Walrus population is mainly concentrated in the Pacific Ocean (approximately 200,000), while there are only around 18,000 walruses in the Atlantic and 5,000 in the Laptev Sea [4].

Received February 2, 2018 / Accepted June 1, 2018

Corresponding author: Apostolos Tsiouvalas

Intern at PAME Secretariat, PAME, Borgir, Norðursloð, Akureyri 600, Iceland

E-mail: postolostsiouvalas@gmail.com 
The walrus plays a dominant role for the Arctic ecosystem, contributes importantly to the Arctic Economies, the diet of the indigenous peoples and the culture of the high north in general. From the 18th through to the mid-20th century the biggest danger for the walruses was commercial hunting [5]. For centuries, people of the North were dependent on subsistence hunting of walruses for food, hides, ivory and bones. This trend dramatically depleted the walrus populations until the 20th Century, when the first conservation measures and conventions took place [6]. Nowadays the commercial hunting of walruses is restricted and only some indigenous populations are still allowed to hunt it for subsistence reasons. Moreover, walruses, together with several other marine carnivores, all the cetaceans and sirenians are protected under the Convention on International Trade in Endangered Species of Wild Fauna and Flora (CITES). The walrus as a species is listed as Vulnerable under criterion A3c in the 'IUCN Red List of Threaten Species' [7]. Therefore, commercial hunting does not compromise any more the walrus populations, which remain stable during the last years. Nowadays, a new pervasive danger has been posed in front of walruses, the threat of the climate change.

The walrus is high dependent on the cryosphere, where the most visible impacts of climate change occur. However, the sensitive mammal has expressed remarkable adaptability to the ongoing changes. Indeed, The U.S. Fish and Wildlife Service announced in October 2017 that, despite its last plans, it will not add the Pacific walrus to the list of threatened species [8]. This statement should not be ignored since thousands of walruses tend to congregate in the coasts of Alaska and seem to be exposed to various dangers. Accordingly, this article was designed as a descriptive study of the dependence of the walrus on the cryosphere addressing the trend of the mammal for adaptation and emphasizing the need for a further reinforcement of its protection, as it derives from official documents, scientific reports and relative articles of scholars.

\section{ROLE OF SEA ICE FOR THE WALRUS SUBSISTENCE}

By looking a map of the walrus distribution around the Arctic someone can easily notice that the livelihoods of walruses are tightly connected to sea ice. Walruses belong to Pinnipeds, many subspecies of which are among the most ice-affiliated marine mammals of the planet [9]. Sea-ice as a core content of the cryosphere plays a crucial role for the survival of walrus, since it uses ice for the satisfaction of most of its biological needs. In particular, walruses use sea ice for crucial behaviours like giving birth in the late spring and feeding and nursing during the summer [10]. During the winter walruses seek drifting pack-ice in order to mate along ice edges [11]. The reliance of walruses on sea ice for resting has been noticed in high levels also during the summer foraging period [12]. Sea ice allows walruses to rest over the feeding banks while drifting around and thereby dispersing the predatory pressure on shellfish resources over larger areas [13]. Walruses use sea ice also as a shelter to be protected from storms and predators [14].

The first changes to the cryosphere in the modern era started around 1900, when Arctic sea ice began to decline, with more accelerated sea ice loss since the 1950s [15]. Satellite records have confirmed since 1979 an overall decrease of summer sea ice coverage of around 13\% per decade [16]. Although fears that Arctic sea ice would reach a 'tipping point' and rapidly disappear currently seem to be baseless, what is possible is the prediction that the Arctic ecosystem will experience ice-free summers within the next 
few decades. The Arctic is being replaced by a warmer, wetter, and more variable environment. This transformation has profound implications for people, resources, and ecosystems worldwide and obviously for the walrus which is a high-depended on ice species. It is worth noting that the rate of seasonal-ice-cover losses in the Atlantic region being faster than the rate in the Pacific region, but the Pacific subspecies would likely be impacted to a greater extent than the Atlantic walrus [17]. However, walrus has so far been adaptable to the current trend of climatic changes in both regions.

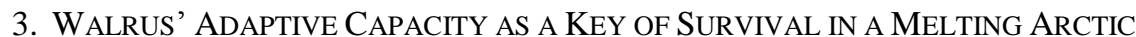

As adaptation can be defined the ability of an organism or group of organisms (such as species) to use any of their structural (morphological or anatomical), physiological, or behavioural characteristics that makes them better suited in its environment and consequently improves their chances of survival and reproductive success [18]. Adaptation is needed in response to changes in the environment or relationship to other organisms. Arctic species are among the most exposed organisms to a changing environment and have certainly experienced the need for adaptation. For instance, between atmospheric climate parameters and habitat parameters present in aquatic and aerial ecosystems, there are linkages which lead to migration. As the global temperature rises, fish species seek their ranges northwards to more favourable conditions, birds lay their eggs earlier than usual, plants bloom earlier and mammals come out of hibernation sooner. As a response to the rise in global temperature, terrestrial and marine mammals' distribution and behaviour is also influenced.

The driving ecological factor for the adaptation of walrus is the reduction of sea-ice. The reliance of walruses on sea ice for crucial behaviours such us nursing, feeding or resting during the summer foraging period makes them particularly vulnerable to changes in climate and the associated loss of sea ice. Ice floes are nowadays much smaller and thinner and able to support only smaller groups of walruses [19]. Walruses can travel to different food sources via ice, while in the absence of ice they must deplete more energy to travel [20]. Therefore, the reduced of sea ice driven by climate change has forced walrus herds to seek new platforms for its basic needs as feeding, mating and resting [21]. However, it is worth to be noticed that the walrus has shown great adaptability to the new climate reality, probably with more success than other species of marine mammals. For example in 1980s there were about 30 haul-out locations along the Bering Sea, where the largest populations of Pacific Walrus are concentrated, while nowadays have significantly been reduced [22]. There is still great deal of division on whether this adaptability is a normal natural behaviour of the mammal which cannot threaten the walrus populations or if it can possibly pose a danger for them in the near future.

The adaptation of walruses to new haul-out patterns is noticed in even higher levels in Chukotka. The haul-out first started to change in the 1990s, when walruses began to haul out annually on land. Sea ice is more frequently disappearing from the continental shelf of the Chukchi Sea during summer months. Walrus started to haul out in numbers that they had never been observed in the past century. During the last years 70,000 to 100,000 individuals can be noticed in one single haul-out location of Chukotka [23]. Over the past 30 years, the walrus range and haul-outs have been moving north [24]. In late fall, much of the walrus population hauls out on the Russian side of the Chukchi after travelling from Point Lay, Alaska, to Serdtse-Kamen in Chukotka covering miles of coast lines [25]. 


\section{UPCOMING TRENDS AND CHALLENGES FOR WALRUSES IN SEA-ICE FREE AREAS}

Walruses tend to travel during the year to find feeding places, while they often concentrate where their food is available [26]. As long as the sea ice declines, more and more Pinnipeds in general are hauling out on land. When the sea ice recedes over the deep ocean basin, walruses must either continue to haul out on the sea ice with little access to food, or abandon the sea ice and move to coastal areas where they can rest on land [27]. Therefore, due to the lack of sufficient sea ice, walruses nowadays tend to congregate on the coasts without ice. This trend can dramatically affect the sensitive mammal directly or even indirectly.

Congregating on sea ice-free coasts means that walruses gradually lose their physical type of haul-out platform since the species uses its biological characteristics to be adapted to the new climatic reality and reassure its survival. For instance, large walrus populations from the Northwest Greenland are seeking terrestrial haul-outs in remote areas of Northeast Nunavut in Canada during summer [28]. However, scientists have noticed that these terrestrial haul-outs are frequently located way far from the feeding banks and the walrus will have to go back and forth from resting places to feeding grounds, consuming a lot of energy compared with drifting on ice pans above the food [29]. Scientists notice that a major remaining concern is the effects of declining sea ice on future energetics of females and young animals that must now make feeding trips from coastal haul-outs to areas of high prey abundance, rather than utilizing nearby ice edges for resting as they did in the past [30]. For example, the Pacific walrus has been recorded to traverse a distance of $180 \mathrm{~km}$ in order to reach its prey [31]. This route definitely renders the species vulnerable to various dangers.

By hauling out on ice free areas the Pinnipeds are more vulnerable to predators and the near-shore prey populations are subjected to greater predation pressure, especially to polar bears which are the main threat to walruses [32]. As response to sea ice melting polar bears tend to hunt on ice-free areas and therefore pose an even bigger danger to walrus populations. Increased mortality rates of walrus calves and yearlings, which are susceptible to being trampled by the far larger adults rushing towards the water in cases of stampede as response to danger, have also been observed [33]. A possible stampede can have a high impact level when all the animals at a haul-out are disturbed and can take a considerable period of several weeks for the herd to return to the haul-out [34]. In the summer, vast numbers of walruses (up to 35 thousands) use the coasts of Point Lay in Alaska to haul out, forced by the retreat of sea ice; not only exposed to predators but also vulnerable to disturbances by the increased ship traffic through the Bering Strait.

Ice-melting can also lead to indirect impacts for the walrus populations which can gradually pose a further danger for the mammal. An ice-free Arctic attracts global interests and offers new opportunities for industrial development and infrastructure construction such as housing, harbours and airports. Shipping within the range of Pacific walruses has been fairly limited in the past primarily due to persistent pack ice in the region [35]. The historical emergence of new sea lanes, which has strongly impacted the international balance of power around the Arctic Ocean, has rapidly exacerbated commercial shipping in Arctic. Consequently, vessel traffic, together with the increasing low-flying aircraft, can provoke even further disturbance to the haul-out places of walruses. Associated with this activity are increasing noise pollution and concerns about shipping accidents that might release oil or other contaminants in the Arctic waters [36]. 
Although no large accidents have been reported so far, oiled wildlife was recorded in 2012 in the vicinity of St. Lawrence Island, albeit with no identified source [37]. Accordingly, indicators showcase as well an abnormal acceleration of touristic development in places where tourists could never access in the past [38].

Due to ice-melting, mineral exploration and extraction has been rendered much more accessible, while commercial fishing in Arctic waters is nowadays less costly than ever before. This interference on the pristine Arctic environment has a profound impact on the livelihood of walruses; it can affect the walruses by further breaking sea ice up, by underwater and atmospheric noise from ships or seismic surveys or even directly by disturbing or even unintentionally catching walruses during fishing operations [39].

Walruses are benthic feeders whose nutrition is dominated by bottom-dwelling sealife and plays a determinant role in the Arctic ecosystem by influencing the structure of benthic invertebrate communities [40]. As walruses root along the seafloor in search of clams and mussels, they plow through large quantities of sediment [41]. They remove large quantities of prey from the seafloor, effect the size structure of clam populations, mix bottom sediments while foraging, create new microhabitats from discarded shells, and generate food for seafloor scavengers from uneaten scraps of prey [42]. These feedback loops can be dramatically affected by bottom trawling fisheries which damage the fragile sea bed [43].

Another possible challenge for both Pacific and Atlantic walruses is the increase of ocean's acidification [44]. Lower $\mathrm{pH}$ levels have already reduced the saturation state of carbonate ions in the water, which can affect the growth, development and survival of the development of calcifying invertebrates, which are significant for the nutrition of walrus [45]. Simultaneously, infectious diseases driven by climate change can be precarious for marine mammals [46]. So far walruses have not been identified as having been infected by diseases, nor by acidification caused by climate change. However, indirect effects of climate change including susceptibility to diseases, parasites and contaminants have already been noticed in seals and whales, and will possibly affect more marine mammals in the near future [47].

\section{LEGAL FRAMEWORK FOR THE PROTECTION OF PACIFIC WALRUS IN THE U.S.A.}

Various legislation has been signed so far for the protection of walrus. The International Maritime Organization (IMO) has adopted the Polar Code, which provides guidelines for safe operations in the Arctic. Marine mammals, and therefore walruses, are protected by the Polar Code which mandates that all ships should consider measures to avoid marine mammals. As derived from the Polar Code, the flag state is responsible for the implementation of the provisions of the Polar Code and, thus, in the case of the U.S. the responsibility falls to the Coast Guard [48].

The U.S. Fish and Wildlife Service (USFWS) has jurisdiction over walrus under the Marine Mammal Protection Act (MMPA) as well. However, this act does not regulate specific measures related to walrus haul-outs, which as mentioned above are mostly risked by the new Arctic circumstances. The avoidance of haul-out disturbances has not yet been a formal project, neither for The Eskimo Walrus Commission (EWC) nor for the Qayassiq Walrus Commission (QWC), which both cooperate with USFWS contributing in reports and paying heed to the implementation of the Mammal Protection Act [49]. In 
addition, the Federal Aviation Administration (FAA), the Bureau of Land Management (BLM) and the Alaska Department of Fish and Game (ADF\&G) have established various guidelines and restrictions related to aviation close to walrus populations [50].

\section{THE RECENT STATEMENT OF USFWS THAT EXCLUDED THE WALRUS FROM THE ENDANGERED LIST}

What is remarkable is that in 2008, the United Stated Fish and Wildlife Service was petitioned to list the Pacific walrus as threatened or endangered under the Endangered Species Act and to designate critical habitat [51]. In 2011, the USFWS found the walrus warranted an endangered listing, largely due to the threat of climate change and loss of Arctic sea ice [52]. However, in the designated list of 2011, USFWS determined that a listing was certainly warranted but precluded by higher priority species [53]. Based on concern about climate change and development, USFWS reconsidered a list scheduling a final decision for 2017 [54]. Finally, the new administration of the U.S. Fish and Wildlife Service announced in October 2017, that there is no clear evidence that walrus are likely to become endangered despite the extensive loss of Arctic sea ice due to global warming [55]. Wildlife advocates are especially concerned about the decision not to list the Pacific walrus, which faces an impending risk as a warming climate deteriorates Arctic ice. Next to the Pacific walrus 28 other species left off the endangered list include turtles, fish, snakes, crustaceans, owls, and woodpeckers, despite the fact that they are threatened by human activities, ranging from water pollution to habitat fragmentation, from urban development to climate change [56].

\section{CONCLUSION: FUTURE TRENDS}

The adaptation of walruses to different climate and dietary needs has been the driving force of their survival during the last years. Thanks to its adaptation to the new circumstances Pacific walrus has not yet been listed as an endangered species by the USFWS. However, this recent statement must not be ignored by the global scientific community.

Haul-outs on ice-free areas are expected to continue and occur more often in the future, particularly in the more northern parts of Alaska and Chukotka [57]. Scientists are concerned that if walruses have to continue to travel at a greater distance in order to find food, they will deplete much more energy than their food can provide [58]. The population will definitely decline, but the extent of decline is yet uncertain [59].USFWS has not made so far a determination under MMPA as to whether the Pacific Walrus is depleted or not.

Climate models project that sea ice will continue to decline, resulting in more ice-free summers of longer duration [60]. Particularly in the Bering Sea, maximum ice extent cover is predicted to decline about $4 \%$ by mid-century and $20 \%$ by late-century, resulting in a one- and three-month increase in the number of ice-free months, respectively [61]. Commercial and cruise shipping will consequently continue and new migrating from warmer regions species would reach soon the Arctic. Urgent actions, further security measures and environmental policies are indispensable in order to avoid further disturbances in walrus haul-out regions. Especially the U.S and Russia, where vast 
numbers of walruses tend to concentrate, need to designate further Protected Areas. New legally binding measures should be regulated, stricter altitude restrictions for shipping and aviation must be applied and USFWS should urgently reconsider its latest decision about not listing the Pacific Walrus under the Endangered Species Act Measures.

What will happen, though, when the species' biological strength for adaptation will be depleted in the shadow of an entirely ice-free Arctic Ocean? Will in this case the walrus populations discover new methods of adaptation for the perpetuation of the species or will their population decrease dramatically, violently urged on by climate change? The coming decades will be rather unpredictable for the 'sensitive giant' while the lives of both Atlantic and Pacific Walrus will be questionably honing in on a hospitable future.

\section{REFERENCES}

1. F.H. Fay, 'Odobenus rosmarus,' Mammalian Species, 238, pp. 1-7, 1985.

2. F.H. Fay, 'Odobenus rosmarus,' Mammalian Species, 238, pp. 1-7, 1985.

3. WWF, 'Walrus,' 2018. Available: http://wwf.panda.org/what_we_do/where_we_work/arctic/wildlife/walrus/

4. WWF, 'Walrus,' 2018. Available: http://wwf.panda.org/what_we_do/where_we_work/arctic/wildlife/walrus/

5. F.H. Fay, 'Ecology and Biology of the Pacific Walrus,' Odobenus rosmarus divergens Illiger. North American Fauna, 74, pp. 1 - 279, 1982.

6. F.H. Fay, 'Ecology and Biology of the Pacific Walrus,' Odobenus rosmarus divergens Illiger. North American Fauna, 74, pp. 1 - 279, 1982.

7. The IUCN Red List of Threatened Species, 'Odobenus rosmarus,' 2017. Available: http://www.iucnredlist. org/details/summary/15106/0

8. United States Fish and Wildlife Service, 'Marine Mammals Management; Walrus and the Endangered Species Act,' 2017. Available: https://www.fws.gov/alaska/fisheries/mmm/walrus/esa.htm

9. F.H. Fay, 'Ecology and Biology of the Pacific Walrus,' Odobenus rosmarus divergens Illiger. North American Fauna, 74, pp. 1 - 279, 1982.

10. B. Ristroph and Pacific Environment, 'Pacific Walrus Protection and Management in a Changing Climate', in Findings from the 2016 Arctic Science Summit Seminar, 2016. Available: http://www.pacificenvironment. org/wp-content/uploads/2017/02/walrus-mgmt-report_final_gl.pdf

11. K.M. Kovacs, P. Lemons, J.G. MacCracken and C. Lydersen,'Walruses in a time of climate change,' 2015. Available: http://www.arctic.noaa.gov/Report-Card/Report-Card-2015/ArtMID/5037/ArticleID/ 226/Walruses-in-a-Time-of-Climate-Change

12. B. Ristroph and Pacific Environment, 'Pacific Walrus Protection and Management in a Changing Climate', in Findings from the 2016 Arctic Science Summit Seminar, 2016. Available: http://www.pacificenvironment.org/ wp-content/uploads/2017/02/walrus-mgmt-report_final_gl.pdf

13. M.P. Heide-Jørgensen, 'Diminishing returns,' in Tesar C (Ed.), Walruses: Going with the floes? (pp.1013), Ottawa, Canada: WWF Arctic Programme, 2017.

14. K.M. Kovacs, P. Lemons, J.G. MacCracken and C. Lydersen,'Walruses in a time of climate change,' 2015. Available: http://www.arctic.noaa.gov/Report-Card/Report-Card-2015/ArtMID/5037/ArticleID/226/Walrusesin-a-Time-of-Climate-Change

15. L. Polyak et Al, 'History of sea ice in the Arctic,' Quaternary Science Reviews, 29, pp. 1757-1778, 2010.

16. National Snow and Ice Data Centre, 'Arctic Sea ice shatters previous low records; Antarctic sea ice edges to record high,' 2012. Available: http://nsidc.org/news/newsroom/20121002_MinimumPR.html

17. J.G. MacCracken, 'Pacific walrus and climate change: Observation and predictions,' Ecol. Evol., 2(8), pp. 2072-2090, 2012.

18. Victorian Centre for Climate Change Adaptation Research, 'Climate change adaptation definitions'. Available: http://www.vcccar.org.au/climate-change-adaptation-definitions

19. K.M. Kovacs, P. Lemons, J.G. MacCracken and C. Lydersen,'Walruses in a time of climate change,' 2015. Available: http://www.arctic.noaa.gov/Report-Card/Report-Card-2015/ArtMID/5037/ArticleID/226/ Walruses-in-a-Time-of-Climate-Change 
20. B. Ristroph and Pacific Environment, 'Pacific Walrus Protection and Management in a Changing Climate', in Findings from the 2016 Arctic Science Summit Seminar, 2016. Available: http://www.pacificenvironment.org/wp-content/uploads/2017/02/walrus-mgmt-report_final_gl.pdf

21. M.P. Heide-Jørgensen, 'Diminishing returns,' in Tesar C (Ed.), Walruses: Going with the floes? (pp.1013), Ottawa, Canada: WWF Arctic Programme, 2017.

22. B. Ristroph and Pacific Environment, 'Pacific Walrus Protection and Management in a Changing Climate', in Findings from the 2016 Arctic Science Summit Seminar, 2016. Available: http://www.pacificenvironment. org/wp-content/uploads/2017/02/walrus-mgmt-report_final_gl.pdf

23. B. Ristroph and Pacific Environment, 'Pacific Walrus Protection and Management in a Changing Climate', in Findings from the 2016 Arctic Science Summit Seminar, 2016. Available: http://www.pacificenvironment. org/wp-content/uploads/2017/02/walrus-mgmt-report_final_gl.pdf

24. Ristroph B and Pacific Environment (2016, May 18) Pacific Walrus Protection and Management in a Changing Climate. Findings from the 2016 Arctic Science Summit Seminar. Available:http://www.pacificenvironment. org/wp-content/uploads/2017/02/walrus-mgmt-report_final_gl.pdf

25. B. Ristroph and Pacific Environment, 'Pacific Walrus Protection and Management in a Changing Climate', in Findings from the 2016 Arctic Science Summit Seminar, 2016. Available: http://www.pacificenvironment. org/wp-content/uploads/2017/02/walrus-mgmt-report_final_gl.pdf

26. B. Ristroph and Pacific Environment, 'Pacific Walrus Protection and Management in a Changing Climate', in Findings from the 2016 Arctic Science Summit Seminar, 2016. Available: http://www.pacificenvironment. org/wp-content/uploads/2017/02/walrus-mgmt-report_final_gl.pdf

27. C.V Jay and A.S. Fischbach, 'Pacific walruses response to Arctic sea ice losses,' in U. S. Geological Survey Fact Sheet 2008-3041, 2012.

28. M.P. Heide-Jørgensen, 'Diminishing returns,' in Tesar C (Ed.), Walruses: Going with the floes? (pp.1013). Ottawa, Canada: WWF Arctic Programme, 2017

29. M.P. Heide-Jørgensen, 'Diminishing returns,' in Tesar C (Ed.), Walruses: Going with the floes? (pp.1013). Ottawa, Canada: WWF Arctic Programme, 2017

30. K.M. Kovacs, P. Lemons, J.G. MacCracken and C. Lydersen,'Walruses in a time of climate change,' 2015. Available: http://www.arctic.noaa.gov/Report-Card/Report-Card-2015/ArtMID/5037/ArticleID/226/Walrusesin-a-Time-of-Climate-Change

31. K.M. Kovacs, P. Lemons, J.G. MacCracken and C. Lydersen,'Walruses in a time of climate change,' 2015. Available: http://www.arctic.noaa.gov/Report-Card/Report-Card-2015/ArtMID/5037/ArticleID/226/Walrusesin-a-Time-of-Climate-Change

32. B. Ristroph and Pacific Environment, 'Pacific Walrus Protection and Management in a Changing Climate', in Findings from the 2016 Arctic Science Summit Seminar, 2016. Available: http://www.pacificenvironment. org/wp-content/uploads/2017/02/walrus-mgmt-report_final_gl.pdf

33. Kovacs KM, Lemons P, MacCracken JG and Lydersen C (2015, November 24) Walruses in a time of climate change. Available: http:/www.arctic.noaa.gov/Report-Card/Report-Card-2015/ArtMID/5037/ArticleID/226/ Walruses-in-a-Time-of-Climate-Change

34. B. Ristroph and Pacific Environment, 'Pacific Walrus Protection and Management in a Changing Climate', in Findings from the 2016 Arctic Science Summit Seminar, 2016. Available: http://www.pacificenvironment. org/wp-content/uploads/2017/02/walrus-mgmt-report_final_gl.pdf

35. J.G. MacCracken, 'Pacific walrus and climate change: Observation and predictions,' Ecol. Evol., 2(8), pp. 2072-2090, 2012.

36. K.M. Kovacs, P. Lemons, J.G. MacCracken and C. Lydersen,'Walruses in a time of climate change,' 2015. Available: http://www.arctic.noaa.gov/Report-Card/Report-Card-2015/ArtMID/5037/ArticleID/226/Walrusesin-a-Time-of-Climate-Change

37. K.M. Kovacs, P. Lemons, J.G. MacCracken and C. Lydersen,'Walruses in a time of climate change,' 2015. Available: http://www.arctic.noaa.gov/Report-Card/Report-Card-2015/ArtMID/5037/ArticleID/226/Walrusesin-a-Time-of-Climate-Change

38. D.B. Stewart and J.W. Higdon, 'The global view: status, trends, and threats,' in C. Tesar (Ed.), Walruses: Going with the floes? (pp.6-10). Ottawa, Canada: WWF Arctic Programme, 2017.

39. J.G. MacCracken, 'Pacific walrus and climate change: Observation and predictions,' Ecol. Evol., 2(8), pp. 2072-2090, 2012.

40. C.V Jay and A.S. Fischbach, 'Pacific walruses response to Arctic sea ice losses,' in U. S. Geological Survey Fact Sheet 2008-3041, 2008.

41. C.V Jay and A.S. Fischbach, 'Pacific walruses response to Arctic sea ice losses,' in U. S. Geological Survey Fact Sheet 2008-3041, 2008

42. C.V Jay and A.S. Fischbach, 'Pacific walruses response to Arctic sea ice losses,' in U. S. Geological Survey Fact Sheet 2008-3041, 2008 
43. T. Arnbom and M. Lancaster, 'Surprisingly sensitive,' in Tesar C (Ed.), Walruses: Going with the floes? (pp.14-15). Ottawa, Canada: WWF Arctic Programme, 2017

44. K.M. Kovacs, P. Lemons, J.G. MacCracken and C. Lydersen,'Walruses in a time of climate change,' 2015. Available: http://www.arctic.noaa.gov/Report-Card/Report-Card-2015/ArtMID/5037/ArticleID/226/Walrusesin-a-Time-of-Climate-Change

45. D.B. Stewart and J.W. Higdon, 'The global view: status, trends, and threats,' in C. Tesar (Ed.), Walruses: Going with the floes? (pp.6-10). Ottawa, Canada: WWF Arctic Programme, 2017.

46. J.J. Lee, 'Is Climate Change Increasing the Disease Risk for Arctic Marine Mammals?,' National Geographic, 2014. Available: https://news.nationalgeographic.com/news/2014/02/140214-seals-belugawhale-arctic-disease-health-science/

47. J.J. Lee, 'Is Climate Change Increasing the Disease Risk for Arctic Marine Mammals?,' National Geographic, 2014. Available: https://news.nationalgeographic.com/news/2014/02/140214-seals-belugawhale-arctic-disease-health-science/

48. B. Ristroph and Pacific Environment, 'Pacific Walrus Protection and Management in a Changing Climate', in Findings from the 2016 Arctic Science Summit Seminar, 2016. Available: http://www.pacificenvironment. org/wp-content/uploads/2017/02/walrus-mgmt-report_final_gl.pdf

49. B. Ristroph and Pacific Environment, 'Pacific Walrus Protection and Management in a Changing Climate', in Findings from the 2016 Arctic Science Summit Seminar, 2016. Available: http://www.pacificenvironment. org/wp-content/uploads/2017/02/walrus-mgmt-report_final_gl.pdf

50. B. Ristroph and Pacific Environment, 'Pacific Walrus Protection and Management in a Changing Climate', in Findings from the 2016 Arctic Science Summit Seminar, 2016. Available: http://www.pacificenvironment. org/wp-content/uploads/2017/02/walrus-mgmt-report_final_gl.pdf

51. United States Fish and Wildlife Service, 'Marine Mammals Management; Walrus and the Endangered Species Act,'2017. Available: https://www.fws.gov/alaska/fisheries/mmm/walrus/esa.htm

52. United States Fish and Wildlife Service, 'Endangered and threatened wildlife and plants; 12-month finding on a petition to list the Pacific walrus as endangered or threatened,' Federal Register (U. S. A.), 76, 7634-7679, 2011.

53. United States Fish and Wildlife Service, 'Endangered and threatened wildlife and plants; 12-month finding on a petition to list the Pacific walrus as endangered or threatened,' Federal Register (U. S. A.), 76, 7634-7679, 2011.

54. B. Ristroph and Pacific Environment, 'Pacific Walrus Protection and Management in a Changing Climate', in Findings from the 2016 Arctic Science Summit Seminar, 2016. Available: http://www.pacificenvironment.org/wp-content/uploads/2017/02/walrus-mgmt-report_final_gl.pdf

55. United States Fish and Wildlife Service, 'Marine Mammals Management; Walrus and the Endangered Species Act,' 2017. Available: https://www.fws.gov/alaska/fisheries/mmm/walrus/esa.htm

56. United States Fish and Wildlife Service, 'Environmental Conservation Online System; Listed Animals', 2018. Available: https://ecos.fws.gov/ecp0/reports/ad-hoc-species-report?kingdom=V\&kingdom= I\&status $=E \&$ status $=T \&$ status $=$ EmE\&status $=$ EmT \&status $=E X P E \&$ status $=E X P N \&$ status $=$ SAE $\&$ status $=$ SAT $\&$ fcrithab $=$ on $\&$ fstatus $=$ on $\&$ fspecrule $=$ on $\&$ finvpop $=$ on $\&$ fgroup $=$ on $\&$ header $=$ Listed + Animals

57. B. Ristroph and Pacific Environment, 'Pacific Walrus Protection and Management in a Changing Climate', in Findings from the 2016 Arctic Science Summit Seminar, 2016. Available: http://www.pacificenvironment.org/wp-content/uploads/2017/02/walrus-mgmt-report_final_gl.pdf

58. K.M. Kovacs, P. Lemons, J.G. MacCracken and C. Lydersen,'Walruses in a time of climate change,' 2015. Available: http://www.arctic.noaa.gov/Report-Card/Report-Card-2015/ArtMID/5037/ArticleID/226/ Walruses-in-a-Time-of-Climate-Change

59. B. Ristroph and Pacific Environment, 'Pacific Walrus Protection and Management in a Changing Climate', in Findings from the 2016 Arctic Science Summit Seminar, 2016. Available: http://www.pacificenvironment. org/wp-content/uploads/2017/02/walrus-mgmt-report_final_gl.pdf

60. J.G. MacCracken, 'Pacific walrus and climate change: Observation and predictions,' Ecol. Evol., 2(8), pp. 2072-2090, 2012.

61. J.G. MacCracken, 'Pacific walrus and climate change: Observation and predictions,' Ecol. Evol., 2(8), pp. 2072-2090, 2012. 


\section{MORŽ: OSETLJIVI GIGANT U ERI KLIMATSKIH PROMENA: ADAPTACIJA NA KLIMATSKE PROMENE I IZAZOVI}

U današnje doba, nema sumnje da se kriosfera menja, temperatura planete povećava, a led povlači. Planeta Zemlja se postepeno suočava sa posledicama globalnog zagrevanja koje su najvidljivije na visokim geografskim širinama, a posebno na Arktiku, koji predstavlja dom Odobenus Rosmarus - a, poznatijeg kao morž. Morž je vrsta čiji opstanak pre svega zavisi od leda. Morževi koriste morski led za ključne aktivnosti tokom života, kao što su rođenje, hranjenje $i$ odmor. Budući da se dinamika ledenog pokrivača na arktičkim morima menja usled promene godišnjih doba, morževi se povlače i okupljaju na obalama gde nema leda. Zahvaljujući adaptaciji morževa na različite klimatske promene, uspešno su preživeli i sačuvali svoje populacije. Njihova prilagodljivost bila je pokretačka snaga koja im je pomogla da ne dospeju listu ugroženih vrsta. Pojedini naučnici ovaj trend pripisuju normalnom adaptivnom ponašanju sisara, dok ostali primećuju da postoji rizik nastao usled klimatskih promena. Imajući u vidu saopštenja Američke službe za ribe $i$ divlje životinje u kojima se navodi da se morževi u bližoj budućnosti neće smatrati ugroženom vrstom, cilj ovog rada je da ukaže na ugroženost morževa dejstvom klimatskih promena, da objasni njihovu zavisnost od morskog leda, kao i potrebu za preispitivanjem gore navedenog saopštenja.

Ključne reči: morž, klimatske promene, adaptacija 